\section{CULTIVATED CROPS IN EARLY ENGLAND}

$\mathrm{I}^{\mathrm{N}}$ VESTIGATIONS of a Danish committee appointed to inquire into the origins and development of agriculture in prehistoric Denmark have developed into a large-scale examination of recorded discoveries of prehistoric grain in northern Europe. In the course of this investigation, which has the support of the Rask-Ørsted Foundation, Dr. Hans Holbok, on behalf of the Committee, visited a number of museums in England, Scotland and Ireland in 1939 for the purpose of examining the remains of prehistoric plants or their impressions on clay vessels from prehistoric and early archæological sites.

Pending fuller publication in collaboration with Prof. Knud Jessen, when that becomes possible, Dr. Holbœk has prepared a preliminary report on his examination of British prehistoric and Anglo-Saxon pottery in the Museum of Archæology and Ethnology in the University of Cambridge, which was completed only shortly before the entry of the Germans into Denmark (Proc. Prehist. Soc., N.S. 6; 1940).

The impressions found and indications of character, summarily stated, are as follows:

Emmer and spelt (Triticum monococcum Sch.). In bronze age barrows and the Late Bronze Age settlement of Mildenhall Fen in the form of impressions of grain and spikelets. T. monococcum L., the closely related small spelt, is also represented. Impressions of the threshed spikelets are characteristic.

Common wheat and club wheat. Distinguishable from emmer grains by thoir more rounded forms. As the evidence exists only in the form of charred grains or impressions, it is rarely possible to distinguish the race. In Cambridge there is only one impression of common wheat ( $T$. vulgare), which comes from an Early Iron Age settlement (Abingdon), and the race seems to have been rare in early England.

Barley. As with wheat having a tough axis, the race of barley is difficult to identify. The prehistoric barley of northern Europe is the six-rowed form (Hordeum polysticum Doll.). It would appear that barley was always the chief grain of the Cambridge area. Naked and husked grains occur with equal frequency in the Bronze Age, but the husked form was almost completely predominant in Anglo-Saxon times.

Oats (Avena sativa). All impressions in the Cambridge material are of threshed oats, that is, without the husks and separated from glume and stem. Oats, presumably brought to Europe in the form of seeds, have been identified in the central European Bronze Age, and possibly were brought to Britain by the Romans. At Cambridge they are noted only in the Anglo-Saxon material.

Flax (Linum usitatissimum). Two flax seed impressions were found in the Anglo-Saxon pottery. In central Europe it is found in late Neolithic times, in Denmark from the Early Iron Age, and in Ireland on a site in Limerick of probably ninth-tenth century A.D.

Woad (Isatis tinctoria). Identified from impressions of the flat-winged fruit. In northern Europe it was cultivated so early as the Iron Age. The Cambridge evidence is of Anglo-Saxon date.

Investigations in other parts of Britain have established the fact that the knowledge of grain growing had already reached the British Isles in the latter part of the Stone Age.

\section{FORTHCOMING EVENTS}

\section{Monday, December 9}

Royal Geographical Society (at Kensington Gore, London, S.W.7), at 3 p.m.-Mr. W. G. East: "The Severn Waterway in the XVIIIth and XIXth Centuries".

\section{Tuesday, December so}

Chemical Engineering Group in conjunction with the Institution of Chemical Engrneers (at the Chemical Society, Burlington House, Piccadilly, London, W.I), at 2.30 p.m.-Dr. A. B. Manning will open a Discussion on "The Salvage of Waste Materials in the Chemical Industry".

Royal Anthropological Institute (also for Members of the Royal Central Asian Society) (at 21 Bedford Square, London, W.C.1), at 2.30 p.m.-M. August Muhlenfeld (Director, West Indian Division, Netherlands Colonial Office): "The Badui : a Primitive Tribe of Eastern Java".

\section{Wednesday, December II}

Royal Society of Arts (at John Adam Street, Adelphi, London, W.C.2), at 1.45 p.m.-Mr. J. S. Nicholl: "Road Transport".

Pharmaceutical Society (at 17 Bloomsbury Square, London, W.C.1), at 2.30 p.m.-Mr. A. L. Bacharach : "Some Nutritional Problems of War and Peace".

\section{Friday, December 13}

Royat Society of ARts (India and Burma Section) (at John Adam Street, Adelphi, London, W.C.2), at 1.45 p.m.-Mr. S. Lall: "Industrial Development in the Indian Provinces".

\section{APPOINTMENTS VACANT}

APPLICATIONs are invited for the following appointments on or before the dates mentioned:

assistant Master to take Physics and Mathematios-The Principal, Twickenham Technical College, Egerton Road, Twickenham, Middx. (December 14).

Graduate Tracher of Mechanical Evgiventivg SubjectsThe Principal, Hendon Technical Institute, The Burroughs, Hendon, London, N.W.4 (December 14).

ADMINISTRATIVE ASSISTANT (MAN) FOR Higher EdUCATION-The ADMINISTRATIVE ASSISTANT (MAN) FOR HIGHER EDUCATION-The
Education Officer, Education Offices, Katherine Street, Croydon (December 16).

Lecturer in Physics and Mathematics-The Principal and Secretary, Harris Institute, Preston (December 21).

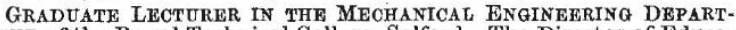
MeNT of the Royal Technical College, Salford-The Director of Education, Education Office, Chapel Street, Salford 3.

\section{REPORTS AND OTHER PUBLICATIONS}

(not included in the monthly Books Supplement) Great Britain and Ireland

Department of Scientiflc and Industrial Research. Methods for the Detection of Toxic Gases in Industry. Leaflet No. 12: Organic Halogen Compounds. Pp. ii 6 . (London: H.M. Stationery Office.) 2d. net.

\section{Other Countries}

Department of Agriculture: Straits Settlements and Federated Malay States. Economic Series, No. 11: Malayan Agricultura Statistics, 1939. By D. H. Gri st. Pp. xii + 102 tables. (Kuala Lumpur Department of Agriculture.) 1 dollar.

U.S. Department of the Interior: Office of Education. Vocationa Division, Bulletin No. 203 (Occupational Information and Guidance Series No. 3): Guidance Programs for Rural High Schools. By Paul W. Chapman. Pp. vi 58. (Washington, D.C. : Government Printing Office.) 10 cents. Transactions of the Academy of Science. Vol. 30, No. 3: The Cytological Structure of the Hypothalamic Nuclei in relation to their Functional Connections. By Homer Dale Kirgis. Pp. 65-86. (St. Iouis, Mo.: Academy of Science.) 50 cents. 